\title{
Fractionation of commercial hexane and use of its fractions as extracting solvent of cottonseed oil
}

\author{
By Ola A. Megahed
}

Fats \& Oils Dept., National Research Centre, Dokki, Cairo, Egypt.

\section{RESUMEN}

Fraccionamiento del hexano comercial y uso de estas fracciones como solvente extractante de aceite de semilla de algodón.

En esta investigación se ha examinado el problema de producir aceite de semilla de algodón sin-clasificar usando hexano comercial producido localmente como disolvente. El objetivo de este trabajo fue investigar si este problema puede ser solucionado controlando el rango de ebullición del disolvente extractante. Cuatro fracciones diferentes de hexano de diversos rangos de ebullición fueron preparadas del hexano comercial. El rango al que ebullía el hexano comercial era $62-68^{\circ} \mathrm{C}$ mientras que los rangos que ebullían las cuatro fracciones eran $62-64,64-65,65-$ 66 y de $66-68^{\circ} \mathrm{C}$. El hexano comercial y las cuatro fracciones de hexano preparadas, fueron luego utilizados para extraer el aceite de semilla de algodón de una muestra de semilla concreta. Las cinco muestras de aceite crudo fueron posteriormente refinadas y decoloradas, y medidos sus colores. Los resultados han mostrado que la fracción más pesada del hexano (b.r. $66-68^{\circ} \mathrm{C}$ ) produjo los aceites más claros. El índice del color del aceite decolorado que usaba esta fracción pesada era 190 comparado al 350 obtenido usado por el hexano comercial original.

Sin embargo, la producción de una fracción de hexano comercial que tenga un estrecho rango de ebullición será costosa. Por tanto, esta investigación se ha ampliado para estudiar la conveniencia del uso de una fracción pesada del petróleo que tenga un rango de ebullición tan amplio como el del hexano comercial para extraer el aceite de semilla de algodón. El rango de ebullición de esta fracción fue $66-72^{\circ} \mathrm{C}$. Los resultados obtenidos mostraron que la extracción del aceite de semilla de algodón usando la fracción pesada del petroleo produce un aceite más claro que con el uso del hexano convencional como disolvente.

PALABRAS-CLAVE: Aceite de semilla de algodón - Extractante - Fraccionamiento - Hexano comercial.

\section{SUMMARY}

Fractionation of commercial hexane and use of its fractions as extracting solvent of cottonseed oil.

The problem of producing off-graded cottonseed oil using locally produced commercial hexane as extracting solvent has explored this research. It was aimed in this work to investigate whether this problem can be solved by controlling the boiling range of the extracting solvent. Four different hexane fractions of different boiling ranges were prepared from commercial hexane. The boiling range of commercial hexane was $62-68^{\circ} \mathrm{C}$ while the boiling ranges of the four fractions were $62-64,64-65,65-66$ and $66-68^{\circ} \mathrm{C}$. Commercial hexane and the prepared four hexane fractions were then used to extract cottonseed oil from a fixed seed sample. The five crude oil samples were then refined and bleached and their colours were measured. The results have shown that the heaviest hexane fraction ( b.r $66-68^{\circ} \mathrm{C}$ ) produced the lightest coloured oils. The colour index of the bleached oil using this heavy cut was 190 compared to 350 using the original commercial hexane.

However, the production of a commercial hexane cut having a narrow boiling range will be costly. Therefore, this research has been extended to investigate the suitability of a heavy petroleum cut which has a boiling range as wide as that of commercial hexane to extract cottonseed oil. The boiling range of this cut was $66-72^{\circ} \mathrm{C}$. The obtained results proved that the extraction of cottonseed oil using that heavy petroleum fraction produces much lighter oil than the use of conventional hexane solvent.

KEY-WORDS: Commercial hexane - Cottonseed oil - Extracting - Fractionation.

\section{INTRODUCTION}

Edible oils represent one of the major requirements in the human diet. Edible oils are usually obtained from oilseeds by extraction. Oilseed extraction can be made by one of three methods; solvent extraction, mechanical pressing and by prepress-solvent extraction. Solvent extraction has the advantage over mechanical methods of extracting greater percentage of the oil from the seed. The percentage of oil left in the meal after solvent extraction usually does not exceed $1 \%$ whereas that by mechanical pressing ranges between $4-7 \%(1)$. However, extraction by solvent yields oils darker in colour. Solvents used in extraction extract in the oil the pigments which occur naturally in the seed.

In Egypt, the major oilseed processed locally is cottonseed. Cottonseed major pigment is gossypol which is yellow in colour, toxic and is acidic in character. Therefore, it can be removed easily in the neutralization step using caustic soda. However, the gossypol may undergo some changes during storage of the seed so that it would lose its acidic character and change at the same time to a much darker pigment (2-4). Therefore, this fixed pigment resists the removal by conventional methods of refining and bleaching. The produced oil; refined or bleached, will be dark coloured and it is graded as a low grade oil. Edible oils should be light enough as to satisfy the consumer and because the price of oils is determined to a certain extent by its colour. 
The pre-mentioned problem can be partially overcome by extracting cottonseed by a solvent which does not extract the fixed gossypol pigment in the crude oil. In Egypt, commercial hexane produced by Alex. Co. For Petroleum; Mex, Alex. is used in oilseed extraction. The boiling range of this hexane is $62-68^{\circ} \mathrm{C}$. Its main constituents are isohexanes and normal hexane, in addition to minor amounts of cyclo hexane and benzene. By varying the boiling range of the hexane cut, its contents of the above components change and hence, its capability to extract the fixed pigment changes.

This paper aims at investigating the effect of the boiling range of the solvent used in cottonseed extraction on the colour of the produced oil. Hence, the most suitable fraction to extract the lightest oil from cottonseed can be identified.

\section{EXPERIMENTAL}

Two Cottonseed samples were used in this investigation. The first sample was an off-graded sample was stored for one year prior to extraction. This fixed sample which contained some of the unrefinable and unbleachable pigments was used in the first phase of the work. This was essential for the primary differentiation between the different solvent fractions according to their selectivity towards such fixed pigments. The solvents used for extraction of this fixed sample were commercial hexane, $H$, (b.r $62-68^{\circ} \mathrm{C}$ ) a product of Alex. Co. for petroleum, Alex. and another four Fractions obtained from this commercial sample. These fractions were coded $A$, $B, C$ and $D$. Their boiling ranges were $62-64^{\circ} \mathrm{C}$, $64-65^{\circ} \mathrm{C}, 65-66^{\circ} \mathrm{C}$ and $66-68^{\circ} \mathrm{C}$ respectively.

In the second part of the work a fresh cottonseed sample was used rather than a stored one. This sample was obtained from the local factories as it would practically represent the seed grade in regular use in the oil industry. The solvents used for the extraction of this fresh seed sample were selected according to the results of the first part of the work. These included commercial hexane $(\mathrm{H})$ and the heavy hexane fraction of boiling range $66-68^{\circ} \mathrm{C}$ (D) which showed the best results regarding the oil colour. Both commercial hexane $(\mathrm{H})$ and the heavy cut $(\mathrm{D})$ were analysed for their composition using gas-liquid chromatographic technique. The analysis was performed on Perkin-Elmer programmed gas chromatograph equipped with flame ionization detector. A capillary column spb-1, 30m length and 0.35 $\mathrm{mm}$ internal diameter was used. The initial temperature was $60^{\circ} \mathrm{C}$ and the final temperature was $300^{\circ} \mathrm{C}$ and the temperature rate was $5^{\circ} \mathrm{C} \mathrm{min}^{-1}$. The carrier gas (Nitrogen) was used at a flow rate of $6 \mathrm{ml} \mathrm{min}^{-1}$.

In addition to the above two solvents, the extraction of cottonseed was also studied using another heavy fraction of boiling range $66-72^{\circ} \mathrm{C}$. This solvent was included in this work as the industrial production of a petroleum fraction of a wider range is easier and more economic.

The oil-solvent mixture obtained after extraction was then distilled under vacuum at $60^{\circ} \mathrm{C}$ to remove the solvent. The crude oils were then refined and bleached. The refining was made using $24^{\circ} \mathrm{Be}$ $\mathrm{NaOH}$ following the procedures of Zeitoun et al.(5). The bleaching was made using $2 \%$ Tonsil clay FF at $110^{\circ} \mathrm{C}$ for about 15 minutes. The colour indices of the refined and bleached oils were then estimated according to the recommendation of Pons et al. (6)as the total of the sixteen absorbances at wave lengths from 400 to $550 \mathrm{~nm} ; 10 \mathrm{~nm}$ intervals and multiplied by 10 . The photometric colour was also calculated using the following equation (7):

$$
\begin{gathered}
\text { Photometric colour }=1.29 \mathrm{Abs}_{(460 \mathrm{~nm})}+69.7 \\
\mathrm{Abs}_{(550 \mathrm{~nm})}+41.2 \mathrm{Abs}_{(620 \mathrm{~nm})}-56.4 \mathrm{Abs}_{(670 \mathrm{~nm})}
\end{gathered}
$$

The absorbances of the refined and bleached oils were measured using Unicam UV Shimadzu spectrophotometer 240 using carbon tetrachloride as a blank.

\section{RESULTS AND DISCUSSION}

The results of this work has been used to investigate the effect of the solvent boiling range on the colour of the oil if extracted from a fixed cottonseed sample and if extracted from a non-fixed sample (fresh).

\subsection{Effect of the solvent boiling range when used with a fixed cottonseed sample}

A fixed cottonseed sample gives a crude oil which contains some unrefinable and unbleachable pigments. The amount of these pigments depends on the extracting solvent and whether it is selective towards such pigments or not. The colour of the bleached oil is therefore finally determined by the solvent selectivity. The least selective solvent fraction yields the lightest coloured oil. The colours of the bleached oils extracted with commercial hexane $(\mathrm{H})$ as well as those extracted using the four solvent fractions $A, B, C$, and $D$ are compared in Figure (1). This Figure shows that the lightest coloured oil can be extracted using the heaviest solvent cut fractionated from commercial hexane which has a boiling range $66-68^{\circ} \mathrm{C}$. The colour index of the oil extracted using this heavy fraction equals 305 for the refined sample and 190 for the bleached sample (Figure 2). The previous colour indices are low compared to those if the oil extraction is made using commercial hexane $(\mathrm{H})$ being 440 and 350 respectively. Regarding the colour index of the dark 


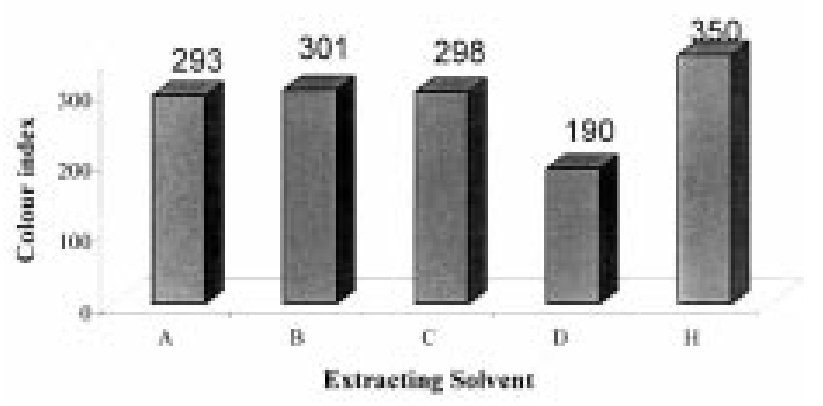

Figure 1

Effect of the boiling range of the extracting solvent on the colour index of bleached oil, from fixed cottonseed samples.

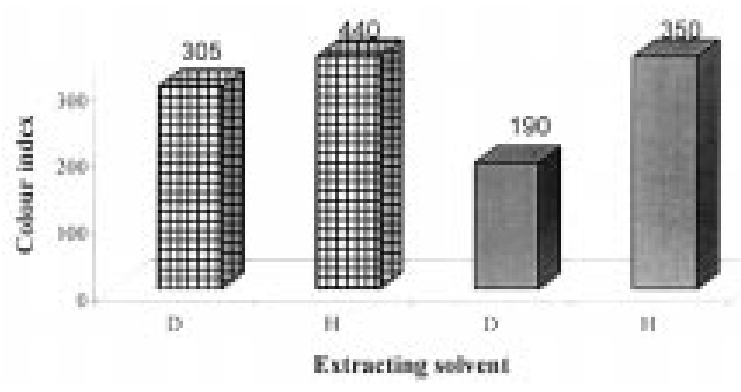

Figure 2

Colour indices of refined and bleached oils extracted using commercial hexane, $\mathrm{H}$ (b.r. 62-68) and heavy fraction, from fixed cottonseed samples, D (b.r. 66-68).

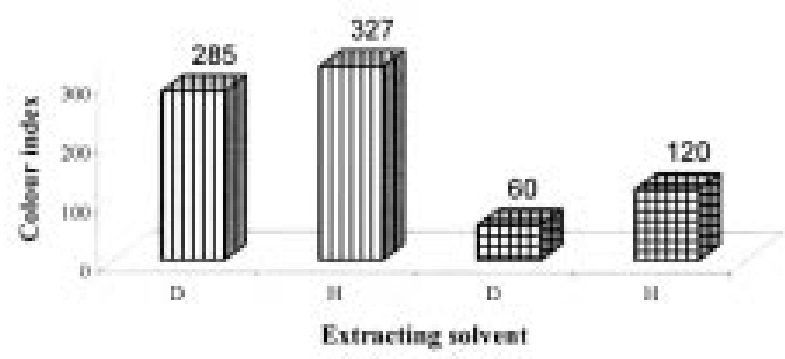

Figure 3

Colour indices of crude and refined oils (diluted ten folds) extracted using commercial hexane, $\mathrm{H}$ and heavy fraction, D (b.r. 66-68), from fixed cottonseed oil

acrude oa

BRothes CA

eBeected oe

crude oil, it was hard to measure without dilution. The colour indices of the crude oils diluted ten folds was 285 for the oil extracted using the heavy hexane cut (D) compared to 328 of that extracted using commercial hexane (Figure 3). Also the photometric colour of the oils; refined and bleached were
Table I

Photometric colour of the oils extracted using commercial hexane, $\mathrm{H}$ and the heavy cut, D from fixed cottonseed sample

\begin{tabular}{|c|c|c|}
\hline \multirow{2}{*}{ Extracting Solvent } & \multicolumn{2}{|c|}{ Photometric Colour } \\
\hline & Refined Oil & Bleached Oil \\
\hline $\begin{array}{c}\text { Commercial hexane, } \mathrm{H} \\
\left.\text { (b.r. } 62-68^{\circ} \mathrm{C}\right)\end{array}$ & 72 & 47 \\
\hline $\begin{array}{l}\text { Heavy cut, D } \\
\text { (b.r. } 66-68^{\circ} \mathrm{C} \text { ) }\end{array}$ & 26 & 14 \\
\hline
\end{tabular}

calculated and found to be 26 and 14 for the refined and bleached samples extracted using the heavy hexane cut (D) compared to and 47, respectively for those extracted using commercial hexane (Table I). This indicates that the oil colour can be reduced to one third its value if the extraction is made using the heavy hexane cut (D).

The percentage reduction in crude oil absorbance over the visible wave length range $(400-550 \mathrm{~nm})$ due to refining and that due to bleaching are compared for the extracted oils in Figures 4 and 5 . The percentage reduction in absorbance due to refining is estimated as the difference between the colour index of the diluted crude oil and that of the diluted refined oil divided by the former and multiplied by hundred. The percentage reduction in oil absorbance due to bleaching is similarly estimated using the absorbance of the non diluted refined and bleached oils. Such estimated reductions reflect the response of the pigments present in the crude oil and in the refined oil to removal by refining and bleaching. The results reveal that the heavy hexane cut extracts pigments which are more refinable and bleachable than those extracted with commercial hexane. In other words, the mixture of components in the heavy fraction (D) is less selective to extract the colour-fixed pigments in cottonseed as compared to commercial hexane $(\mathrm{H})$.

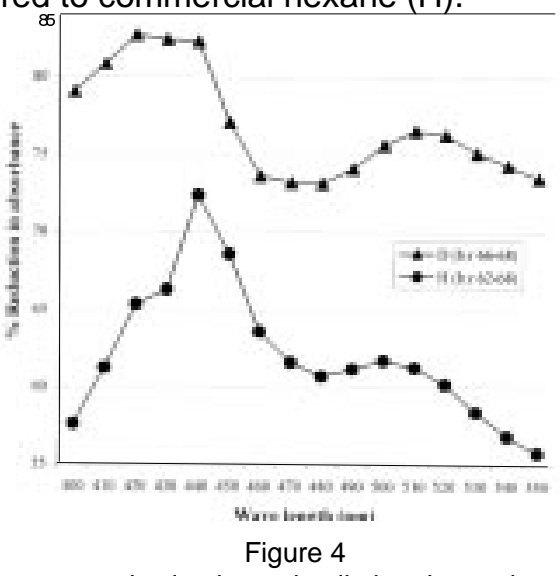

Percentage reduction in crude oil absorbance by refining. 


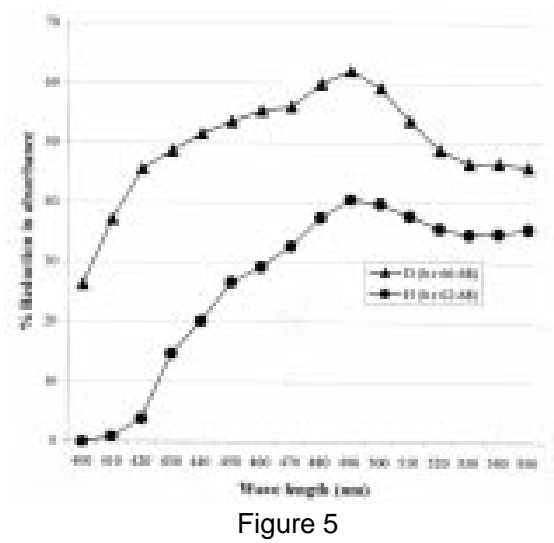

Percentage reduction in refined oil absorbance by bleaching.

Table II

Composition of commercial hexane and the heavy cut as detected by GLC analysis

\begin{tabular}{ccccc} 
Solvents & \multicolumn{4}{c}{ PERCENTAGES } \\
\cline { 2 - 5 } & $\begin{array}{c}\text { Components } \\
\text { iso- } \\
\text { hexanes }\end{array}$ & $\begin{array}{c}\text { normal } \\
\text { hexane }\end{array}$ & $\begin{array}{c}\text { Cyclo } \\
\text { hexane }\end{array}$ & Benzene \\
\hline $\left.\begin{array}{c}\text { Commercial hexane, } \mathrm{H} \\
\text { (b.r. 62-68 }\end{array}{ }^{\circ} \mathrm{C}\right)$ \\
$\begin{array}{c}\text { Heavy cut, D } \\
\text { (b.r. 66-68 }\end{array}$ & 44.5 & 41.9 & 13.1 & 0.5 \\
\hline
\end{tabular}

Table II compares the composition of the heavy hexane fraction (D) to that of the original commercial hexane $(\mathrm{H})$. It is clear that the percentage of iso-hexane is lower in the heavy cut (D) whereas the percentage of the other components; normal hexane and cyclo hexane are greater. It can be understood that the selectivity of a solvent to extract the undesirable pigments decreases as the iso-hexane percentage in this solvent decreases and as the percentages of normal hexane and cyclo hexane increase.

\subsection{Effect of the solvent boiling range when used with a non-fixed cottonseed sample (fresh)}

The effect of the boiling range of the extracting solvent when used with fresh sample of cottonseed which is in regular use in local factories is shown in Figures 6 and 7 as well as Tables III and IV. These results compare the performance of three solvents only being commercial hexane $(\mathrm{H})$ the heaviest cut fractionated from commercial hexane (D) in addition to a petroleum fraction of boiling range from 66 to $72^{\circ} \mathrm{C}(\mathrm{E})$. It is clear that the extraction of cottonseed oil using a petroleum fraction of boiling range

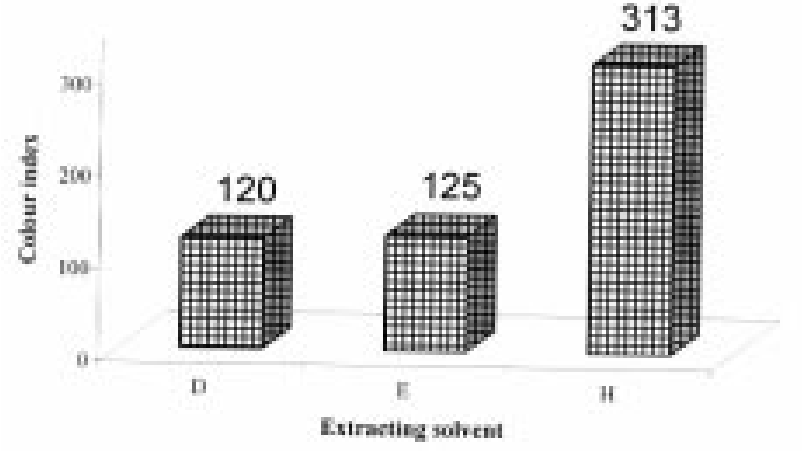

Figure 6

Effect of the boiling range of the extracting solvent on the colour index of the refined oil from non-fixed cottonseed samples.

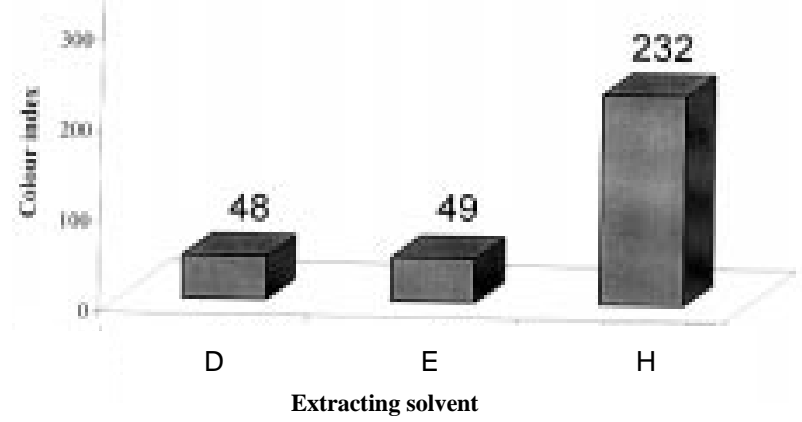

Figure 7

Effect of the boiling range of the extracting solvent on the colour index of the bleached oil, from non fixed cottonseed samples.

$\mathrm{D}\left(\mathrm{b} . \mathrm{r} 66-68^{\circ} \mathrm{C}\right) \quad \mathrm{E}\left(\mathrm{b} . \mathrm{r} 66-72{ }^{\circ} \mathrm{C}\right) \quad \mathrm{h}\left(\mathrm{b} . \mathrm{r} 62-68^{\circ} \mathrm{C}\right)$

$66-72^{\circ} \mathrm{C}$ instead of commercial hexane (b.r $62-68^{\circ} \mathrm{C}$ ) produced much lighter oil. This will be reflected on a marked reduction of the quantities of sodium hydroxide and that of bleaching earth used in refining and bleaching processes. This, in turn , will greatly decrease the oil losses in these processes. Reduction of oil losses means considerable financial benefit to the oil producing company.

Table III

Photometric colour of the oils extracted using commercial hexane; $H$, the heavy cut; $D$ and solvent, $\mathrm{E}$ from non fixed cottonseed sample

\begin{tabular}{ccc}
\hline Extracting Solvent & \multicolumn{2}{c}{ Photometric colour } \\
\cline { 2 - 3 } & Refined oil & Bleached oil \\
\hline $\begin{array}{c}\text { Commercial hexane }(\mathrm{H}) \\
\left.\text { (b.r. } 62-68^{\circ} \mathrm{C}\right)\end{array}$ & 36 & 29 \\
$\begin{array}{c}\text { Heavy hexane cut (D) } \\
\left.\text { (b.r. } 66-68^{\circ} \mathrm{C}\right)\end{array}$ & 6 & 4 \\
$\begin{array}{c}\text { Petroleum fraction }(\mathrm{E}) \\
\left(\text { b.r. } 66-72^{\circ} \mathrm{C}\right)\end{array}$ & 6 & 4 \\
\hline
\end{tabular}


Table IV

Lovibond colour of the oils extracted using commercial hexane; $\mathrm{H}$, the heavy cut;

$D$ and solvent; $E$.

\begin{tabular}{|c|c|c|c|c|c|c|}
\hline \multirow{3}{*}{ Extracting Solvent } & \multicolumn{6}{|c|}{ Bleached oil } \\
\hline & \multicolumn{3}{|c|}{ Refined Oil } & \multicolumn{3}{|c|}{ Bleached Oil } \\
\hline & Y & R & $Y+10 R$ & Y & & R \\
\hline $\begin{array}{c}\text { Commercial hexane }(\mathrm{H}) \\
\left.\text { (b.r. } 62-68^{\circ} \mathrm{C}\right)\end{array}$ & 8.0 & 4.1 & 49.0 & 10.0 & 2.3 & 3.3 \\
\hline $\begin{array}{l}\text { Heavy hexane cut (D) } \\
\left.\text { (b.r. } 66-68^{\circ} \mathrm{C}\right)\end{array}$ & 8.0 & 0.3 & 11.0 & 2.0 & 0.0 & 2.0 \\
\hline $\begin{array}{l}\text { Petroleum fraction (E) } \\
\left.\text { (b.r. } 66-72^{\circ} \mathrm{C}\right)\end{array}$ & 8.0 & 0.5 & 13.0 & 2.0 & 0.0 & 2.0 \\
\hline
\end{tabular}

\section{CONCLUSION AND RECOMMENDATION}

In view of the results of this work it can be concluded that the extraction of cottonseed oil using a petroleum fraction of boiling range $66-72^{\circ} \mathrm{C}$ instead of commercial hexane currently used in local oil factories will yield lighter coloured oil and will reduce the oil losses in refining and bleaching.

Therefore, it is recommended that the company which produces commercial hexane in Egypt should adjust the conditions of petroleum fractionation as to produce a fraction of boiling range from 66 to $72^{\circ} \mathrm{C}$ to be used in the process of oilseed extraction in the oil and soap sector.

\section{REFERENCES}

1. Bailey, A. E. Industrial Oils and Fats Products Edited by Hui , Y. H. , $5^{\text {th }}$ Edition, John Wiley 2 (1996) 18-74.

2. Zaher, F. A., El-Nomany, H. M and El-Shami, S. M Studies on Fixation of Gossypol Pigments. Seifen le Fette Wachse, 114 (8) (1988) 317-318.

3. Zaher, F. A., Aly, S. M. and Mohammed, S. S. The Effect of Atmospheric Oxygen on the Conversion Rate of Gossypol Pigment to Unrefinable Form The Egyptian Journal of Food Science, 19 (3) (1991) 365 $-374$.

4. Zaher, F. A., Mohammed, S. S and Helmy, H. E. Kinetics of Gossypol Conversion to Unrefinable Form. Egyptian Journal of Food Science 20 (1) (1992).

5. Zeitoun, M. A and Harris, W. D. Refining of Crude Cottonseed Oil Dissolved in Hexane J. Am. Oil Chem. Soc. 39 (1962) 286-289.

6. Pons, W. A., Jr. ; Kuck, J. C. and Frampton, V. L. Colour Index for Cottonseed Oils. J. Am. Oil Chem. Soc. 37 (1960) 671.

7. Zaher, F. A. Solvent Extraction of Cottonseed Oil with Petroleum Solvents with Special Reference to Local Solvents. M.Sc. Thesis, College of Engineering, Cairo University (1971). 